\title{
Canakinumab treatment in patients with active recurrent or chronic TNF-receptor associated syndrome (TRAPS): Efficacy and safety results from a proof of concept study
}

\author{
H Lachmann ${ }^{1 *}$, M Cattalini $^{2}$, L Obici ${ }^{3}$, R Barcellona ${ }^{4}$, A Speziale $^{5}$, Y Joubert ${ }^{5}$, G Junge ${ }^{5}$, M Gattorno $^{6}$ \\ From 8th International Congress of Familial Mediterranean Fever and Systemic Autoinflammatory Diseases \\ Dresden, Germany. 30 September - 3 October 2015
}

\section{Introduction}

Tumor necrosis factor receptor-1 associated periodic syndrome (TRAPS) is a periodic fever syndrome, characterized by recurrent fever attacks associated with rashes, musculoskeletal and abdominal pain, and periorbital edema. In few patients TNF inhibitors have been shown to be effective, however, their efficacy tends to decrease over time [1-4]. Anti-IL-1 treatments have also been used in an effort to provide long term control of the inflammatory manifestations.

\section{Objectives}

The main objective was to determine whether canakinumab (CAN) induced complete or almost complete response in patients with active TRAPS at Day 15, as defined by Physician's Global Assessment (PGA). Evolution of $\mathrm{C}$-reactive protein (CRP) and serum amyloid $\mathrm{A}$ (SAA), relapse rate and time to remission were additional measures. An additional objective was to determine the appropriate dosing for further development of CAN treatment in TRAPS patients.

\section{Patients and methods}

This was an open-label, single treatment arm, efficacy and safety study of monthly CAN $150 \mathrm{mg}(2 \mathrm{mg} / \mathrm{kg}$ for patient $\leq 40 \mathrm{~kg}) \mathrm{SC}$ in patients with active recurrent or chronic TRAPS [NCT01242813]. Patients were treated for 4-months with a maximum 5-month follow-up period. The initial follow-up period was followed by a maximum

${ }^{1}$ University College London, London, UK

Full list of author information is available at the end of the article 24-month long-term treatment period. Here we report the efficacy and safety results of the completed study.

\section{Results}

A total of 20 patients were exposed to study medication, out of which 18 (90\%) patients completed the study. At Day 15, complete response or almost complete response was achieved in 18 patients [90\%; 95\% CI: 75.1, 99.9], while $20(100 \%)$ and $12(60 \%)$ patients had clinical and serological remission, respectively. Already at Day 8, 16 patients $(80 \%)$ achieved a complete or almost complete response, while 18 (90\%) and 7 (35\%) patients had clinical and serological remission, respectively. A total of $60 \%$ of patients experienced study drug-related AEs, most commonly upper respiratory tract infections. Seven patients (35\%) experienced SAEs, none of which were related to study drug. Furthermore, there were no deaths during the study.

\section{Conclusions}

Canakinumab was effective in rapidly improving clinical signs and symptoms of TRAPS, whilst normalizing serological inflammatory markers and providing sustained disease control. The safety profile was consistent with previous canakinumab studies in other indications. These data support the ongoing development of canakinumab in this therapeutic area.

\footnotetext{
Authors' details

'University College London, London, UK. ${ }^{2}$ Pediatric Clinic, University of Brescia, Brescia, Italy. ${ }^{3}$ Policlinico S. Matteo, Pavia, Italy. ${ }^{4}$ Hospital Sciacca, Sciacca, Italy. ${ }^{5}$ Novartis Pharma AG, Basel, Switzerland. ${ }^{6} \mathrm{G}$ Gaslini Institute, Genova, Italy.
} 
Published: 28 September 2015

\section{References}

1. Simon A, et al : Am.J.Med 2004, 117:208-210.

2. Weyhreter $H$, et al : J Pediatr 2003, 142:191-193.

3. Jacobelli S, et al : Rheumatology 2007, 46(7):1211-1212.

4. Arostegui J, et al : Eur.J.Pediatr 2005, 164:13-16.

doi:10.1186/1546-0096-13-S1-059

Cite this article as: Lachmann et al:: Canakinumab treatment in patients with active recurrent or chronic TNF-receptor associated syndrome (TRAPS): Efficacy and safety results from a proof of concept study. Pediatric Rheumatology 2015 13(Suppl 1):O59.

Submit your next manuscript to BioMed Central and take full advantage of:

- Convenient online submission

- Thorough peer review

- No space constraints or color figure charges

- Immediate publication on acceptance

- Inclusion in PubMed, CAS, Scopus and Google Scholar

- Research which is freely available for redistribution

Submit your manuscript at www.biomedcentral.com/submit
Ciomed Central 